\title{
High molecular weight of polysaccharides from Hericium erinaceus against amyloid beta-induced neurotoxicity
}

\author{
Jai-Hong Cheng ${ }^{1}$, Chia-Ling Tsai ${ }^{2}$, Yi-Yang Lien ${ }^{3}$, Meng-Shiou Lee ${ }^{4 *}$ and Shyang-Chwen Sheu ${ }^{2 *}$
}

\begin{abstract}
Background: Hericium erinaceus (HE) is a well-known mushroom in traditional Chinese food and medicine. HE extracts from the fruiting body and mycelia not only exhibit immunomodulatory, antimutagenic and antitumor activity but also have neuroprotective properties. Here, we purified HE polysaccharides (HEPS), composed of two high molecular weight polysaccharides $\left(1.7 \times 10^{5} \mathrm{Da}\right.$ and $\left.1.1 \times 10^{5} \mathrm{Da}\right)$, and evaluated their protective effects on amyloid beta (Aß)-induced neurotoxicity in rat pheochromocytoma PC12 cells.

Methods: HEPS were prepared and purified using a $95 \%$ ethanol extraction method. The components of HEPS were analyzed and the molecular weights of the polysaccharides were determined using high-pressure liquid chromatography (HPLC). The neuroprotective effects of the polysaccharides were evaluated through a 2,2-diphenyl-1-picrylhydrazyl (DPPH) radical scavenging assay and an MTT assay and by quantifying reactive oxygen species (ROS) and mitochondrial membrane potentials (MMP) of A $\beta$-induced neurotoxicity in cells.

Result: Our results showed that $250 \mu \mathrm{g} / \mathrm{ml}$ HEPS was harmless and promoted cell viability with $1.2 \mu \mathrm{M} \mathrm{A} \beta$ treatment. We observed that the free radical scavenging rate exceeded $90 \%$ when the concentration of HEPS was higher than $1 \mathrm{mg} / \mathrm{mL}$ in cells. The HEPS decreased the production of ROS from 80 to $58 \%$ in a dose-dependent manner. Cell pretreatment with $250 \mathrm{\mu g} / \mathrm{mL}$ HEPS significantly reduced Aß-induced high MMPs from 74 to $51 \%$ and 94 to $62 \%$ at 24 and 48 h, respectively. Finally, $250 \mu \mathrm{g} / \mathrm{mL}$ of HEPS prevented A $\beta$-induced cell shrinkage and nuclear degradation of PC12 cells.
\end{abstract}

Conclusion: Our results demonstrate that HEPS exhibit antioxidant and neuroprotective effects on A $\beta$-induced neurotoxicity in neurons.

Keywords: Hericium erinaceus, Polysaccharides, Amyloid beta, Neuroprotection, PC12 cell

\section{Background}

Hericium erinaceus (HE) is a well-known mushroom that is consumed as food and used in traditional Chinese medicine. These mushrooms contain physiologically significant components, such as $\beta$-glucan polysaccharides and other biomaterials, which have demonstrated anticancer, immunomodulatory, hypolipidemic, antioxidant and neuroprotective properties [1-6]. As an anticancer agent, the polysaccharides from HE have more significant anti-

\footnotetext{
* Correspondence: leemengshiou@mail.cmu.edu.tw; ssheu@mail.npust.edu.tw ${ }^{4}$ Department of Chinese Pharmaceutical Sciences and Chinese Medicine Resources, China Medical University, Taichung, Taiwan

${ }^{2}$ Department of Food Science, National Pingtung University of Science and

Technology, No. 1, Shuehfu Rd, Neipu, Pingtung, Taiwan

Full list of author information is available at the end of the article
}

artificial pulmonary metastatic tumor effects and immunomodulatory activity than those of Hericium laciniatum [1]. HE and Lentinus edodes have been compared with regard to their antitumor activities and immunoregulatory effects on mice with sarcoma 180 [7]. Additionally, HE extracts (HTJ5 and HTJ5A) have been found to be more effective and less toxic than clinically used anticancer drugs such as 5-fluorouracil against liver cancer HepG2 and Huh-7, colon cancer HT-29 and gastric cancer NCI-87 cells in vitro and in tumor xenografts in vivo [8].

Macrophages are activated by HE polysaccharides to produce nitric oxide and express cytokines (IL-1beta and TNF-beta), which lead to effective antitumor activity and immunomodulation [9]. Previously, we demonstrated that 
HE extracts can induce the activation of dendritic cells and increase the secretion of IL-12 to modulate a TH1 immune response [2]. The hypolipidemic effects proportionally increased with oral administration of an $\mathrm{HE}$ exo-biopolymer in a dose-dependent manner in animal studies [3]. The HE biomaterials reduced levels of lowdensity lipoprotein cholesterol while maintaining relatively high levels of high-density lipoprotein cholesterol and reduced the risk of atherosclerosis.

It was previously reported that $\mathrm{HE}$ extracts have neuroprotective effects, promote normal development of cultivated cerebellar cells and have regulatory effects on the development of myelin genesis processes in vitro [10]. The ethanol extract of HE has been shown to induce nerve growth factor expression and to prevent $A \beta_{25-35}$-induced impairment of memory functions in animal experiments $[11,12]$. Oxidative stress has been shown to be involved in the initiation and progression of various disorders caused by oxygen radicals, which damages lipids, proteins and nucleic acids $[13,14]$. The hot water extract of $\mathrm{HE}$ has been reported to improve this free radical scavenging activity and inhibit lipid peroxidation [15]. HE polysaccharide extracts have been reported to decrease lipid peroxidation levels, increase antioxidant enzyme activity and increase radical scavenging activity $[4,16,17]$.

In this study, we purified HEPS, which consists of two high molecular weight polysaccharides and exhibits antioxidant activity, from fruiting bodies. HEPS-treated cells showed an increase in the rate of free radical scavenging, a reduction in the production of ROS, a recovery in mitochondrial function, maintenance in morphology changes, and a reduction in cell apoptosis of PC12 cells upon $A \beta$ treatment. Finally, we demonstrated that HEPS has neuroprotective properties for neurons.

\section{Methods}

\section{Cell culture}

PC12 cells were purchased from the Bioresource Collection and Research Center of the Food Industry and Development Research Institute in Taiwan. Cells were grown in RPMI 1640 with $10 \%$ heat inactivated horse serum, $5 \%$ fetal bovine serum, penicillin (50 units $/ \mathrm{ml}$ ), and streptomycin $(50 \mathrm{mg} / \mathrm{ml})$. The cells were cultivated in an incubator with $5 \% \mathrm{CO}_{2}$ at $37^{\circ} \mathrm{C}$.

\section{Preparation of HEPS}

Fresh fruiting bodies of HE were obtained from a local farm as previously reported [2]. Samples of HE were identified by Professor Wen-Te Chang of China Medical University (CMU) in Taiwan. The HE voucher specimen and number (CPSCMU HE 1021202) were deposited to the School of Chinese Medicine Resources (SCMR) at CMU. A modified procedure from Dr. Mori's report was used to prepare HEPS [11]. The whole fruiting body was cleaned, lyophilized and powdered. The HE powder was mixed with two volumes of ethanol (95\%) and homogenized at $200 \mathrm{rpm}$ for $1 \mathrm{~h}$. This procedure was repeated three times. The mixture was then filtered with Whatman filter paper (Sigma-Aldrich, USA), and the extract was collected by centrifuging the mixture at $10,000 \times \mathrm{g}$ for $10 \mathrm{~min}$ at $4{ }^{\circ} \mathrm{C}$. The HEPS supernatant was then lyophilized and stored at $-20{ }^{\circ} \mathrm{C}$ until used for experiments.

\section{Measuring components and molecular weights of HEPS}

The total sugars and reducing sugars in the extract were measured as previously described [2]. The Bradford method was used to determine the total concentration of protein using a protein assay kit (Bio-Rad, USA) following the manufacturer's instructions. Flavonoids from HEPS were measured using previously described methods [18]. Flavonoid content curves were determined using quercetin as a standard. The endotoxicity of HEPS was measured using a chromogenic Limulus amebocyte lysate kit (Associates of Cape Cod, USA), where the maximum sensitivity level was $0.25 \mathrm{EU} / \mathrm{mL}$ [2].

The molecular weights of HEPS components were determined by HPLC analysis. The extract was dissolved in deionized water, filtered through a $0.45 \mu \mathrm{m}$ membrane and applied to a Hitachi L-2490 HPLC system (Tokyo, Japan) as a $20 \mu \mathrm{L}$ aliquot. The system was fit with a TSK-GEL G3000PWXL column $(7.8 \mathrm{~mm} \times 30 \mathrm{~cm})$ and was maintained at a temperature of $25^{\circ} \mathrm{C}$. The extract was eluted with deionized water at a flow rate of $0.6 \mathrm{~mL} / \mathrm{min}$ and detected by a refractive index detector (RID). Pullulan standards of various molecular weights (5900, 11,800, $22,800,47,300$, and 112,000 daltons) were used to establish standard curves and to determine molecular weights [2].

\section{DPPH radical scavenging assay}

The free radical scavenging rate was evaluated by measuring the 2,2-diphenyl-1-picrylhydrazyl (DPPH) scavenging activity of HEPS. The DPPH assay used a modified procedure from a previously described study [19]. The HE extracts were dissolved in methanol and mixed with $250 \mu \mathrm{L}$ of a $0.2 \mathrm{mM}$ DPPH radical solution (Sigma-Aldrich, USA). After $30 \mathrm{~min}$ at room temperature, the absorbance of the resulting solutions and a blank were recorded against $0.1 \mathrm{mg} / \mathrm{mL}$ butylated hydroxyanisole (BHA) and L-ascorbic acid (Vitamin C; Sigma-Aldrich, USA) as positive controls. The absorbance of each reaction was recorded in triplicate. The disappearance of DPPH radicals was measured spectrophotometrically at $517 \mathrm{~nm}$ using a Hitachi U-2001 spectrophotometer (Tokyo, Japan), and the DPPH scavenging effect was calculated as previously described [19].

\section{MTT assay for cell cytotoxicity and protection}

The MTT assay was used for three experiments. First, the cell cytotoxicity of HEPS was measured by plating 
exponentially growing PC12 cells at a density of $5 \times 10^{4}$ cells/well in 96-well plates, which were exposed with or without 25, 50, 100, 200, $250 \mu \mathrm{g} / \mathrm{mL}$ of HEPS for 24 and $48 \mathrm{~h}$. The second stage of the assay measured cell cytotoxicity of $\mathrm{A} \beta_{1-40}$ (Sigma-Aldrich, USA) by adding $1.2 \mu \mathrm{M} \mathrm{A} \beta_{1-40}$ to PC12 cells for 24 and $48 \mathrm{~h}$. The third stage was a cell protection assay, in which PC12 cells were incubated with $25,50,100,200,250 \mu \mathrm{g} / \mathrm{mL}$ of HEPS for $24 \mathrm{~h}$, and $1.2 \mu \mathrm{M} \mathrm{A} \beta_{1-40}$ was added for 24 and $48 \mathrm{~h}$. After each of these three experiments, the cells were incubated with $2 \mathrm{mg} / \mathrm{mL}$ 3-(4,5-dimethylthiazol-2-yl)-2,5diphenyl tetrazolium bromide (MTT) for $4 \mathrm{~h}$ at $37^{\circ} \mathrm{C}$, the media was carefully removed and $100 \mu \mathrm{l}$ of DMSO was added to each well. Dark blue formazan crystals formed, the intact cells were solubilized for $30 \mathrm{~min}$, and the absorbance at $570 \mathrm{~nm}$ was measured with a PowerWave XS ELISA reader (Bio-Tek, USA). The results were expressed as the percentage of MTT reduction, assuming the absorbance of control cells was $100 \%$.

\section{ROS and MMP measurements}

To measure ROS, cells treated with HEPS and $A \beta_{1-40}$ were collected and centrifuged at $650 \times \mathrm{g}$ for $10 \mathrm{~min}$. The resulting pellets were washed once with phosphate buffered saline (PBS). These steps were repeated twice. The ROS production rate was measured using an OxiSelect ${ }^{\mathrm{tm}}$ Intracellular ROS Assay Kit, and the intracellular accumulation of ROS was monitored using the cell-permeable fluorogenic probe 2,7'-dichlorodihydrofluorescein diacetate (DCFH-DA).

The MMP was measured using the fluorescent dye JC-1 [20]. Mitochondria with high MMP promoted the formation of J-aggregates and fluoresced red. In contrast, mitochondria with low MMP contained JC-1 monomers and fluoresced green. After co-treating cells with $1.2 \mu \mathrm{M}$ A $\beta_{1-40}$ for $24 \mathrm{~h}$ in the presence or absence of HEPS, $1 \times 10^{6}$ cells/ $\mathrm{mL}$ were collected and incubated for $15 \mathrm{~min}$ at $37^{\circ} \mathrm{C}$. JC-1 $(10 \mu \mathrm{g} / \mathrm{mL})$ was then loaded, and the fluorescence intensity of the cells was examined at an excitation of $485 \mathrm{~nm}$ and emission of $535 \mathrm{~nm}$ using FACScan flow cytometry (Becton Dickinson, USA).

\section{Cell morphology and intracellular fluorescence staining}

The DNA-binding dye acridine orange (Sigma-Aldrich, USA) was used to observe the morphological characteristics of the treated cells. After PC12 cells were incubated with $1.2 \mu \mathrm{M} \mathrm{A} \beta_{1-40}$ or HEPS at $37{ }^{\circ} \mathrm{C}$ for 24 and $48 \mathrm{~h}$, the cells were washed with sterilized PBS three times and incubated with acridine orange $(10 \mu \mathrm{g} / \mathrm{ml})$ at $37^{\circ} \mathrm{C}$ for $10 \mathrm{~min}$ in the dark. The stained cells were observed and photographed using an Olympus COVER-018 fluorescence microscope (Tokyo, Japan).

\section{Statistical analysis}

The data were analyzed using Statistical Analysis System (SAS) software (SAS Institute, USA) as described previously [2]. A one-way analysis of variance (one-way ANOVA) and Duncan's test were used to determine the statistical significance between groups. Differences were considered statistically significant when $p \leq 0.05$.

\section{Results and discussion}

\section{The composition and cell toxicity of HEPS}

The fruiting bodies of HE were cleaned, lyophilized and powdered. The powder of HE was extracted using $95 \%$ alcohol, and lyophilization afforded HEPS. The composition of HEPS was then analyzed as shown in Table 1. The total sugar content was determined to be $311 \mathrm{mg} / \mathrm{g}$, while the reducing sugar content was $249 \mathrm{mg} / \mathrm{g}$. Furthermore, the total amount of protein was $135 \mu \mathrm{g} / \mathrm{g}$. As previously reported, flavonoids are directly associated with the daily human dietary intake of antioxidants and are important for health benefits, neuroprotection and may potentially delay the development of Alzheimer's disease (AD)-like pathology [21-23]. We determined that the flavonoid concentration in HEPS was $99 \mathrm{ng} / \mathrm{g}$ using quercetin as a standard. The molecular weight of HEPS components were measured by HPLC analysis. The retention times were 9.5 and $10.4 \mathrm{~min}$ and the molecular weights of the individual components were $1.7 \times 10^{5}$ daltons and $1.1 \times 10^{5}$ daltons, respectively (Fig. $1 \mathrm{a}$ ). The molecular weights of these major components were different from those in our previous study $\left(2.2 \times 10^{4}\right.$ daltons), which used different purification procedures [2]. Bioactive polysaccharides that are higher in molecular weight have been shown to exhibit significant antitumor properties, immunomodulatory activity, antioxidant activity, and neuroprotection $[24,25]$. In this study, we purified the high molecular weight polysaccharides from HE and tested their neuroprotective properties.

Prior to the experiments, endotoxin contamination levels were examined and determined to be lower than $0.25 \mathrm{EU} /$ $\mathrm{mL}$. Results from the cell cytotoxicity assay (MTT assay) are shown in Fig. 1b and c. Different concentrations of HEPS ( 25 to $250 \mu \mathrm{g} / \mathrm{mL}$ ) were added to PC12 cells and incubated for 24 and $48 \mathrm{~h}$. There was no significant difference in cell viability after incubation for $24 \mathrm{~h}(125,129,131,130$ and $133 \%)$ and $48 \mathrm{~h}(139,141,140,137$ and $149 \%)$ with different HEPS concentrations compared to $\mathrm{N}^{+}$(complete medium; $121 \pm 7.1 \%$ for $24 \mathrm{~h}$ and $139 \pm 8.3 \%$ for $48 \mathrm{~h}$ ) as shown in Fig. 2. The results indicate that HEPS was harmless to $\mathrm{PC} 12$ cells.

Table 1 Compositions of the extract from Hericium erinaceus

\begin{tabular}{lllll}
\hline Content Total sugar Reducing sugar Protein Flavonoids &
\end{tabular}

\begin{tabular}{lllll}
\hline Extract $(\mathrm{mg} / \mathrm{g})$ & $311 \pm 27.8^{\mathrm{a}}$ & $249 \pm 25.8^{\mathrm{a}}$ & $135 \pm 0.1^{\mathrm{a}}$ & $99 \pm 1.7^{\mathrm{a}}$
\end{tabular}

The values are shown as mean \pm SD $(n=3)$ 


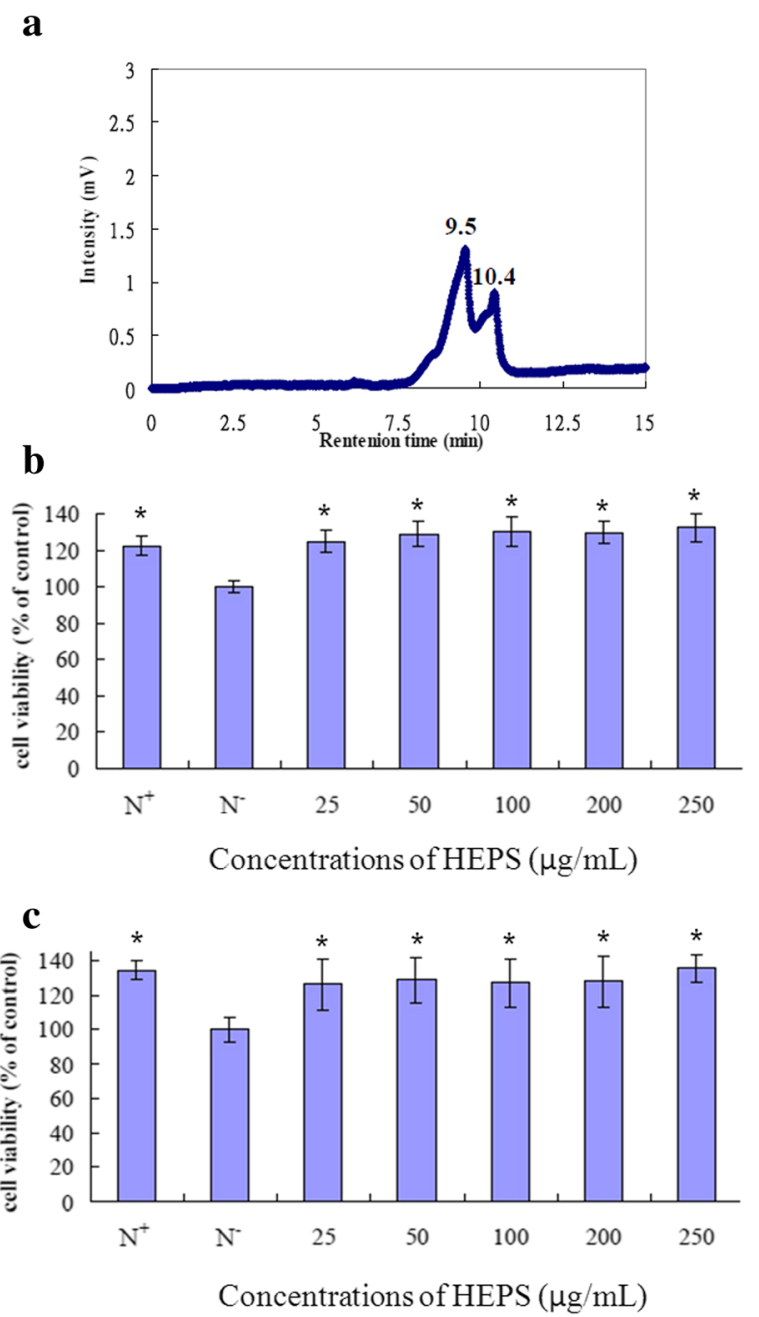

Fig. 1 Measuring the molecular weight and toxicity of HEPS. a The molecular weight of HEPS was measured by HPLC. b 24 and (c) $48 \mathrm{~h}$ PC12 cell incubation with different concentrations of HEPS $(25,50$, 100,200 and $250 \mu \mathrm{g} / \mathrm{mL}$, respectively). Cell viability was measured by an MTT assay with HEPS. RPMI-1640 complete medium containing $10 \%$ horse serum and $5 \%$ fetal bovine serum is indicated as $\mathrm{N}^{+}$. Serum-free RPMI-1640 medium is indicated as $\mathrm{N}^{-}$. All values are mean \pm SD and used a one-way analysis of variance (ANOVA, $n=6$ ). All columns were significantly different compared with $\mathrm{N}^{-}$and are indicated as * $(p<0.05)$

\section{HEPS protecting PC12 cells against $A \beta_{1-40}$ induced neurotoxicity}

Accumulation of $\mathrm{A} \beta$ is considered to play a crucial role in the initiation and progression of $\mathrm{AD}[26,27]$. AD-associated neurotoxic mechanisms include oxidative stress, mitochondrial dysfunction, and apoptosis, which cause abnormal neuronal function. We utilized different concentrations of $A \beta_{1-40}$ to induce cytotoxicity and evaluated cells with the MTT assay. As shown in Fig. 3a and b, $1.2 \mu \mathrm{M}$ of $\mathrm{A} \beta_{1-40}$ significantly decreased cell viability from 100 to $8 \%$ and $6 \%$ after treatment for 24 and $48 \mathrm{~h}$. Nevertheless, we

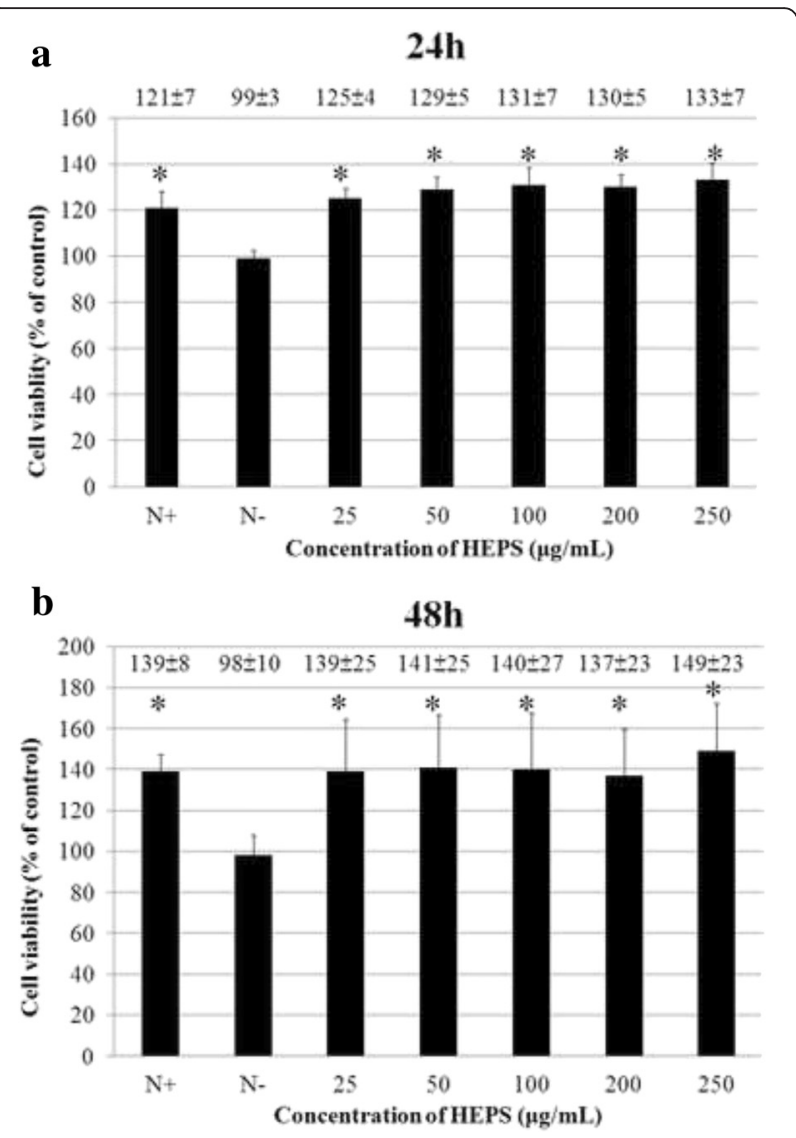

Fig. 2 The cell viability of PC12 cells with HEPS. a, (b) PC12 cells were treated with different concentrations $(0,25,50,100,200$ and $250 \mu \mathrm{g} / \mathrm{mL})$ of HEPS and incubated for 24 and $48 \mathrm{~h}$. Cell viability measurements were used to evaluate cell death using the MTT assay. Serum-free RPMI-1640 medium is indicated as $\mathrm{N}^{-}$. All values are mean $\pm \mathrm{SD}$ and used a oneway analysis of variance (ANOVA, $n=6$ ). All columns were significantly different $(p<0.05)$

explored the dose-dependent attenuating effects of HEPS pre-treatment on $\mathrm{A} \beta_{1-40}$-induced toxicity (Fig. $3 \mathrm{c}$ and $\mathrm{d}$ ). Cell viability improved to 89 and $69 \%$ with $250 \mu \mathrm{g} / \mathrm{mL}$ of HEPS after incubation with $A \beta_{1-40}$ for 24 and $48 \mathrm{~h}$. HEPS concentrations higher than $250 \mu \mathrm{g} / \mathrm{mL}$ were also measured, but there were no improvements in neuroprotective effects (data not shown). Researchers have reported that polysaccharide extracts and their derivatives from parts of plants and mushrooms not only had immunomodulatory abilities but also improved neuronal growth and protection [2, 25, 28-30]. Polysaccharide extracts from Lycium barbarum have been shown to have neuroprotective effects against fibrillar $A \beta_{1-40}$ and $A \beta_{25-35}$ fragment toxicity, as well as improved learning, memory and neurogenesis in animal studies [25, 31, 32]. Additional therapeutic effects of HEPS and its derivatives require further studies. Finally, our results demonstrated that HEPS had protective benefits against $A \beta$ cytotoxicity in PC12 cells. 

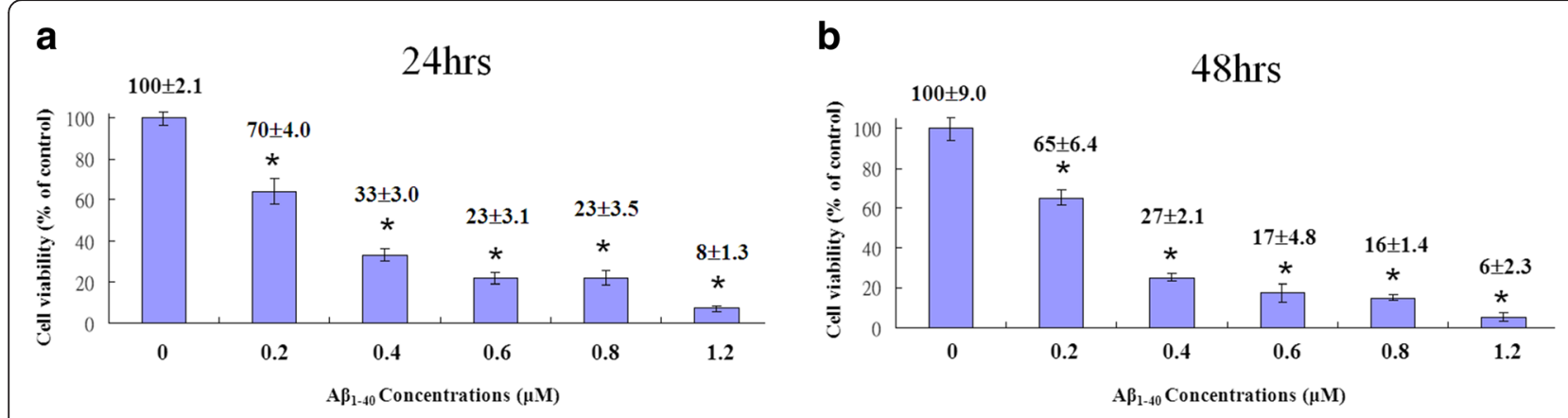

C

d
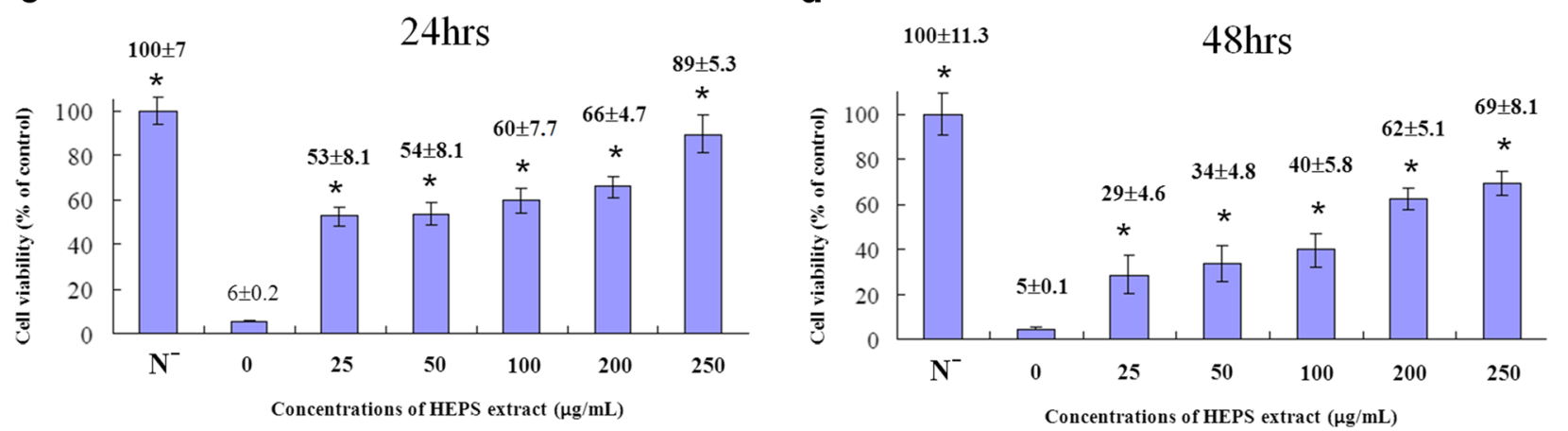

Fig. 3 The protective effects of HEPS on Aß-induced toxicity in PC12 cells. $\mathbf{a}$, (b) PC12 cells were treated with different concentrations of $A \beta_{1-40}$ $(0,0.2,0.4,0.6,0.8$ and $1.2 \mu \mathrm{M})$ for 24 and $48 \mathrm{~h}$ and the toxicity was analyzed. $\mathbf{c}$, (d) PC12 cells were treated with different concentrations $(0,25,50,100$, 200 and $250 \mu \mathrm{g} / \mathrm{mL}$ ) of HEPS followed by addition of $1.2 \mu \mathrm{M} \mathrm{A} \beta_{1-40}$ and incubation for 24 and $48 \mathrm{~h}$. Cell viability measurements were used to evaluate cell death using the MTT assay. Serum-free RPMI-1640 medium is indicated as $\mathrm{N}^{-}$. All values are mean \pm SD and used a one-way analysis of variance (ANOVA, $n=6)$. All columns were significantly different $(p<0.05)$

HEPS inhibited accumulation of free radical and ROS in cells Polysaccharides extracted from Antrodia cinnamomea and other mushrooms have demonstrated antioxidant properties that involve up-regulation of glutathione S-transferase (GST) activity, maintenance of normal glutathione (GSH)/ oxidized glutathione (GSSG) ratios, and scavenging of ROS [33]. In order to survey the antioxidant activity of HEPS, DPPH assays were carried out to measure free radical scavenging. Different concentrations of HEPS (0.1, 0.5, 1, 1.5 and $2 \mathrm{mg} / \mathrm{mL}$ ) were added into PC12 cells and the scavenging effects were monitored (Fig. 4a). BHA and Vit $\mathrm{C}$ were added as positive controls. Over $90 \%$ of scavenging free radicals were detected at $1 \mathrm{mg} / \mathrm{mL}$ of HEPS. The highest quantity of scavenging free radicals (97\%) was detected at $2 \mathrm{mg}$ / $\mathrm{mL}$ of HEPS. As previously reported, HEPS cultivated in Malaysia exhibited antioxidant properties and over a $90 \%$ scavenging effect at $7 \mathrm{mg} / \mathrm{mL}$ [4]. Selenium-containing polysaccharides in HE shake flask cultures reached $100 \%$ antioxidant activity at $5 \mathrm{mg} / \mathrm{mL}$ while an absence of selenium exhibited a less pronounced antioxidant activity of $72 \%$ at the same concentration [34]. These results indicate that our methods of preparing HEPS produced polysaccharides with greater antioxidant activity.

Mitochondria are a major source of ROS, which are produced in many normal and abnormal physiological processes [35]. However, excessive ROS production may cause damage during the accumulation of $A \beta$ in the pathogenesis of $\mathrm{AD}$ [36]. As shown in Fig. 4b, pretreatment of HEPS at concentrations ranging from $25 \mu \mathrm{g} / \mathrm{mL}$ to $250 \mu \mathrm{g} / \mathrm{mL}$ significantly decreased the production of ROS from 80 to $58 \%$ after $A \beta$ incubation for $24 \mathrm{~h}$. Moreover, $250 \mu \mathrm{g} / \mathrm{mL}$ HEPS considerably reduced ROS levels to $40 \%$ compared to cells without HEPS pretreatment, suggesting that HEPS protects mitochondria and reduces ROS generation.

\section{HEPS prevents loss of MMP in PC12 cells}

Growing evidence suggests that high $A \beta$ levels result in mitochondrial abnormalities through a mechanism that is not clearly established [37]. Both the amyloid precursor protein (APP) and $A \beta$ have been found in mitochondrial membranes and interact with mitochondrial proteins. Overproduction of these proteins has been found to increase interruptions in electron transfer and to impair mitochondrial function $[38,39]$. To further examine the protective effect of HEPS in mitochondrial function, we measured the loss of mitochondrial membrane potential using the JC-1 dye to functionally stain mitochondria in PC12 cells [20]. Cells were treated with $1.2 \mu \mathrm{M} \mathrm{A} \beta_{1-40}$ for 24 and $48 \mathrm{~h}$, and flow cytometry indicated that MMPs were 

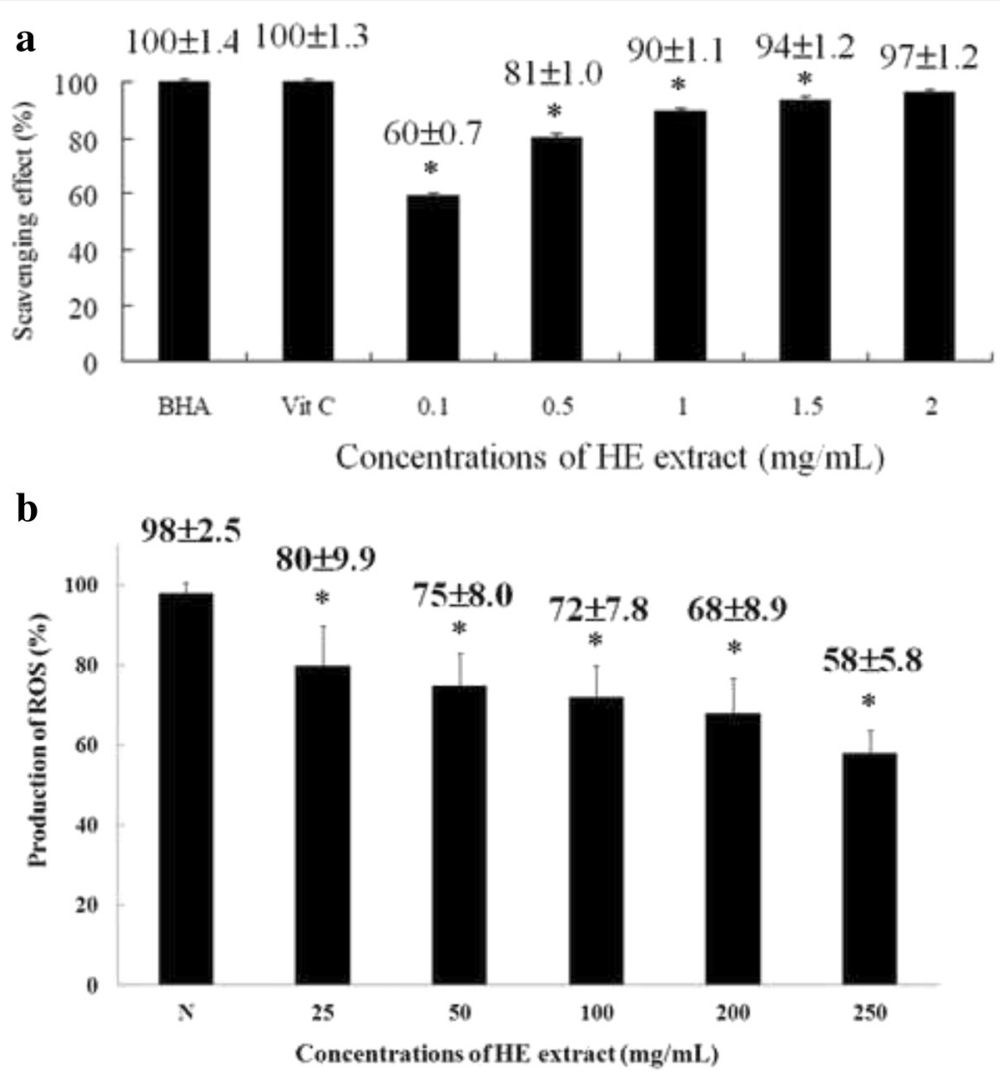

Fig. 4 The scavenging activity of HEPS and production of ROS on A 3 -induced neurotoxicity in PC12 cells upon pretreatment of HEPS. a Different concentrations $(0.1,0.5,1,1.5$ and $2 \mathrm{mg} / \mathrm{mL})$ of HEPS were added into PC12 cells the free radical scavenging activity was measured using the DPPH assay. BHA and Vit C ( $0.1 \mathrm{mg} / \mathrm{mL})$ were used as positive controls. b The effect of HEPS $(25,50,100,200$ and $250 \mu \mathrm{g} / \mathrm{mL})$ on the production of ROS was followed by $1.2 \mu \mathrm{M}$ Aß-induced neurotoxicity in PC12 cells. The production of ROS was measured using an ROS assay kit. N indicates samples without HEPS. All values are mean \pm SD and used a one-way analysis of variance (ANOVA, $n=3$ in panel A and $n=6$ in panel B). All columns were significantly different $(p<0.05$ )

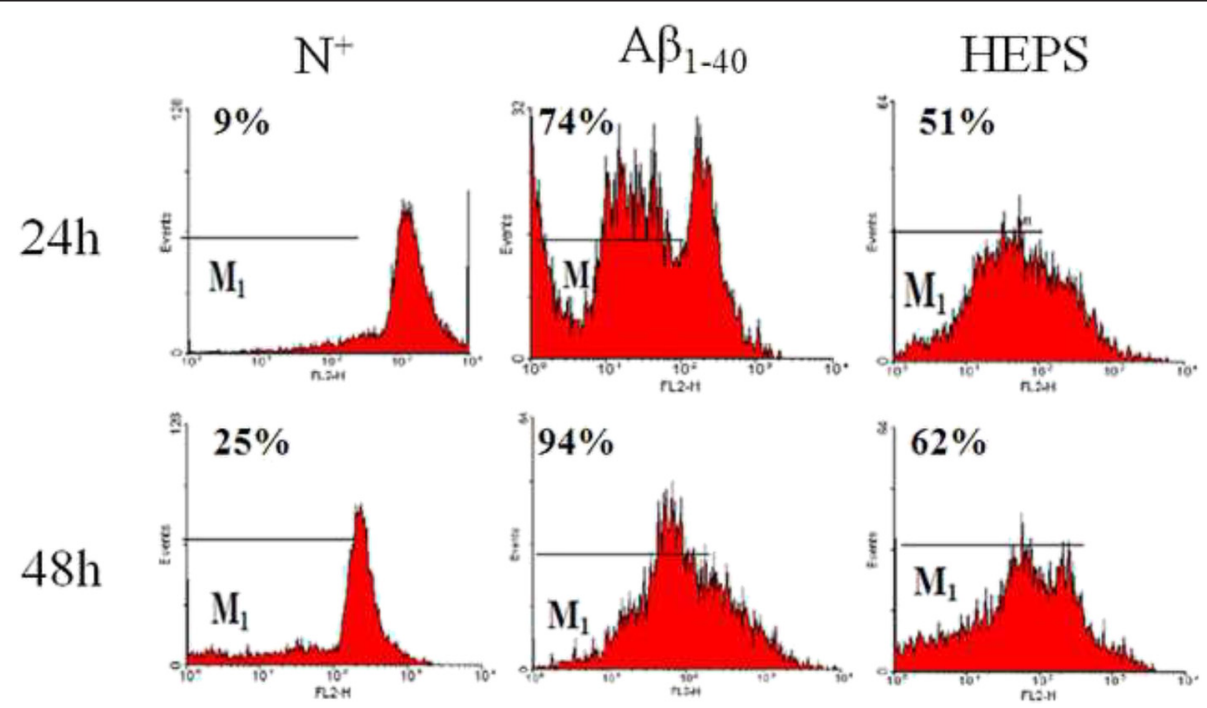

Fig. 5 Measurement of MMP in PC12 cells. Cells were incubated with $1.2 \mu \mathrm{M} \mathrm{A} \beta_{1-40}$ for 24 and $48 \mathrm{~h}$ and MMP changes were measured using FACScan flow cytometry. MMPs were then reduced by pretreating samples with $250 \mu \mathrm{g} / \mathrm{mL}$ HEPS followed by $1.2 \mu \mathrm{M} \mathrm{A} \beta_{1-40}$. RPMI-1640 complete

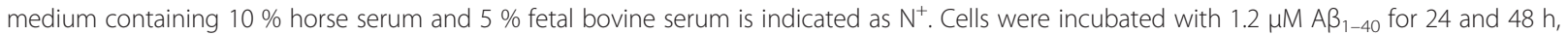
and MMP changes were measured using FACScan flow cytometry. MMPs were reduced by pretreating samples with $250 \mu \mathrm{g} / \mathrm{mL} \mathrm{HEPS}$ followed by $1.2 \mu \mathrm{M} \mathrm{A} \beta_{1-40}$. RPMI-1640 complete medium containing $10 \%$ horse serum and $5 \%$ fetal bovine serum are indicated as $\mathrm{N}^{+}$ 
reduced and the green fluorescence of JC1 monomer increased to 74 and $94 \%$ in PC12 cells (Fig. 5). Pretreatment with HEPS showed that mitochondrial functions were protected, and MMP recovery decreased to 51 and $61 \%$ after 24 and $48 \mathrm{~h}$ of $\mathrm{A} \beta$ incubation. Dr. Eckert reported that Ginkgo biloba extract EGb 761 significantly improved the MMP of PC12 cells in a dose dependent manner and also treated age-related cognitive disorders such as $\mathrm{AD}$ [40]. Our results show that $A \beta_{1-40}$ changed mitochondrial function and that HEPS protected against $\mathrm{A} \beta_{1-40}$-induced abnormalities in the MMP of mitochondria in PC12 cells.

\section{Measurement of morphology and intracellular changes}

The aggregation of $A \beta_{1-40}$ induces neuronal damage such as the breakdown of oligodendrocytes and the emergence of shrunken cell bodies [41]. PC12 cells ruptured and shrunk with $A \beta_{1-42}$ treatment after 24 and 48 h (Fig. $6 a$ and b; $A \beta_{1-42}$ treatment). However, these damages were less significant in cell cultures containing $250 \mu \mathrm{g} / \mathrm{mL}$ HEPS followed by incubation with $A \beta_{1-42}$ (Fig. 6a and b; HEPS treatment). We also used acridine orange staining to observe fragmentation and rupture of cellular nuclei, which formed apoptotic bodies (Fig. 6b; comparing $A \beta_{1-42}$ and HEPS). Pretreatment with HEPS reduced PC12 cell apoptosis and decreased cellular damage. These observations suggest that HEPS could reduce cell apoptosis and may have the ability to protect cells.

The compound CBNU06 is purified from Isodon japonicas and protects $\mathrm{PC} 12$ cells from $\mathrm{A} \beta$-induced neurotoxicity and reduces the number of cells that undergo DNA condensation and fragmentation by inhibiting NF-kB signaling pathways [42]. Atractylodes macrocephala polysaccharides have demonstrated neuroprotective effects by decreasing the expression of Bax and Caspase-3 and increasing Bcl-2 levels in neurons [43]. However, the actual mechanism of protecting and reducing cell apoptosis by HEPS needs further investigation. a

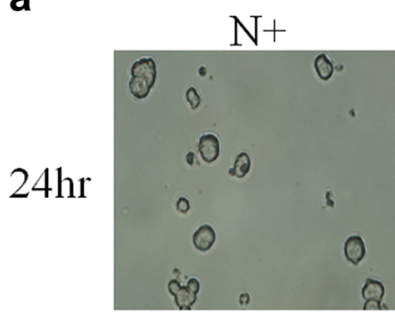

$48 \mathrm{hr}$

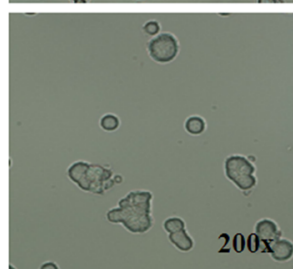

b
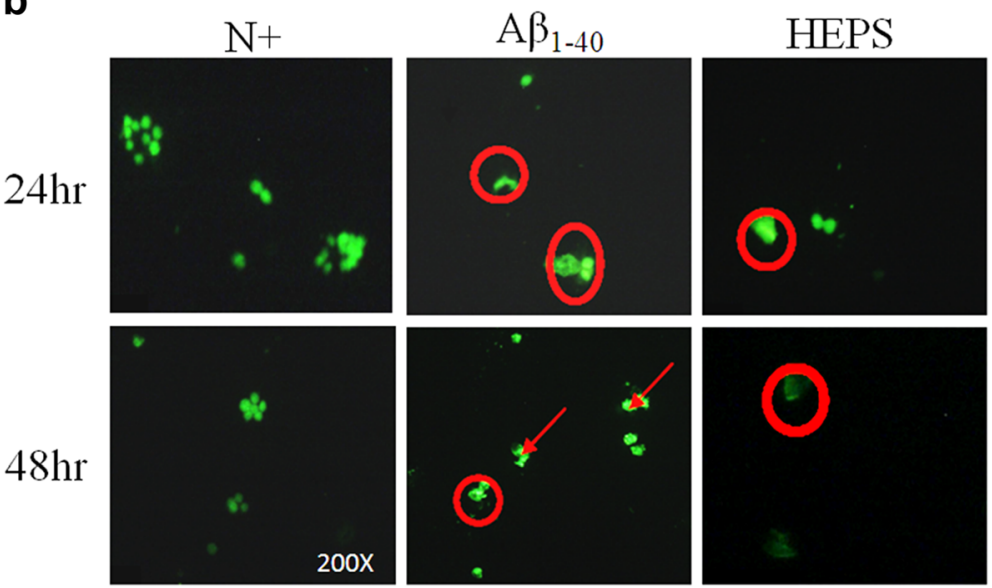

Fig. 6 Morphological changes in PC12 cells were induced by A 3 , and cells were protected by pretreatment with HEPS. a Morphological changes in PC12 cells were observed by microscope after incubation with $1.2 \mu \mathrm{M} \mathrm{A} \beta_{1-40}$ for 24 and $48 \mathrm{~h}$. b PC12 cells were protected by HEPS ( $\left.250 \mu \mathrm{gg} / \mathrm{mL}\right)$ followed by incubation with $1.2 \mu \mathrm{M} \mathrm{A} \beta_{1-40}$ for 24 and $48 \mathrm{~h}$. Intracellular fluorescence was observed by fluorescence microscopy. RPMl-1640 complete medium containing $10 \%$ horse serum and $5 \%$ fetal bovine serum are indicated as $\mathrm{N}^{+}$. Circles and arrows indicate nuclear fragments and cell rupture, respectively 


\section{Conclusions}

Our results demonstrate that pretreatment of PC12 cells with HEPS, which contains two high molecular weight polysaccharides, promotes antioxidant activity and has neuroprotective effects against on $\mathrm{A} \beta$-induced neurotoxicity. We show that HEPS promoted cell viability under A $\beta$-induced toxic conditions. Furthermore, HEPS also increased the efficacy of free radical scavenging and ROS. Finally, HEPS protected PC12 cells against A $\beta$-induced cell apoptosis. In summary, our previous and current findings suggest that different molecular weight polysaccharides from $\mathrm{HE}$ not only play a role in immunomodulation of dendritic cells but also contain neuroprotective effects for neurons.

\section{Abbreviations}

$A D$, Alzheimer's disease; $A P P$, amyloid precursor protein; $A \beta$, amyloid beta; BHA, butylated hydroxyanisole; DCFH-DA, 2', 7'-Dichlorodihydrofluorescin diacetate; DPPH, 2,2-diphenyl-1-picrylhydrazil; GSH, glutathione; GSSG, oxidized glutathione; GST, glutathione S-transferase; HE, Hericium erinaceus; HPLC, high pressure liquid chromatography; MMP, mitochondrial membrane potential; MTT, 3- (4,5-cimethylthiazol-2-yl)-2,5-diphenyl tetrazolium bromide; PBS, phosphate buffered saline; RID, refractive index detector; ROS, reactive oxygen species; SAS, Statistical Analysis System

\section{Acknowledgments}

The authors would like to thank all of the colleagues and students who contributed to this study.

\section{Funding}

This study is partially supported by a grant from the Chang Gung Research Foundation (CMRPG 8C1351).

\section{Availability of data and materials}

The datasets supporting the conclusions of this article are included within this article.

\section{Authors' contributions}

$J H C$, SCS, and MSL participated in this study with primary duties including the conception and design of the study, data analysis, data interpretation, drafting the article and final approval of the version to be submitted. CLT participated in this study with primary duties in reference searches, data analysis and data interpretation. YYL participated in this study with primary duties in data acquisition, data analysis, reference searches and final approval of the version to be submitted.

\section{Competing interests}

The authors declare that they have no competing interests.

\section{Consent for publication}

Not applicable.

\section{Ethics approval and consent to participate}

Not applicable.

\footnotetext{
Author details

'Department of Medical Research, Center for Shockwave Medicine and Tissue Engineering, Kaohsiung Chang Gung Memorial Hospital and Chang Gung University College of Medicine, Kaohsiung, Taiwan. ${ }^{2}$ Department of Food Science, National Pingtung University of Science and Technology, No. 1, Shuehfu Rd, Neipu, Pingtung, Taiwan. ${ }^{3}$ Department of Veterinary Medicine, National Pingtung University of Science and Technology, No. 1, Shuehfu Rd, Neipu, Pingtung, Taiwan. ${ }^{4}$ Department of Chinese Pharmaceutical Sciences and Chinese Medicine Resources, China Medical University, Taichung, Taiwan.
}

Received: 13 October 2015 Accepted: 28 May 2016

Published online: 07 June 2016

\section{References}

1. Wang JC, Hu SH, Su CH, Lee TM. Antitumor and immunoenhancing activities of polysaccharide from culture broth of Hericium spp. Kaohsiung J Med Sci. 2001;17(9):461-7.

2. Sheu S-C, Lyu Y, Lee M-S, Cheng J-H. Immunomodulatory effects of polysaccharides isolated from Hericium erinaceus on dendritic cells. Process Biochem. 2013;48(9):1402-8.

3. Yang BK, Park JB, Song CH. Hypolipidemic effect of an Exo-biopolymer produced from a submerged mycelial culture of Hericium erinaceus. Biosci Biotechnol Biochem. 2003;67(6):1292-8.

4. Wong KH, Sabaratnam V, Abdullah N, Kuppusamy UR, Naidu M. Effects of cultivation techniques and processing on antimicrobial and antioxidant activities of hericium erinaceus (Bull..Fr.) Pers. Extracts. Food Technol Biotechnol. 2009;47(1):47-55.

5. Lai PL, Naidu M, Sabaratnam V, Wong KH, David RP, Kuppusamy UR, et al. Neurotrophic properties of the Lion's mane medicinal mushroom, Hericium erinaceus (Higher Basidiomycetes) from Malaysia. Int J Med Mushrooms. 2013;15(6):539-54

6. Khan MA, Tania M, Liu R, Rahman MM. Hericium erinaceus: an edible mushroom with medicinal values. J Complement Integr Med. 2013;10. doi:10.1515/jcim-2013-0001.

7. Liu C, Gao P, Qian J, Yan W. Immunological study on the antitumor effects of fungus polysaccharides compounds. Wei Sheng Yan Jiu. 2000;29(3):178-80.

8. Li G, Yu K, Li F, Xu K, Li J, He S, et al. Anticancer potential of Hericium erinaceus extracts against human gastrointestinal cancers. J Ethnopharmacol. 2014;153(2):521-30

9. Lee JS, Min KM, Cho JY, Hong EK. Study of macrophage activation and structural characteristics of purified polysaccharides from the fruiting body of Hericium erinaceus. J Microbiol Biotechnol. 2009;19(9):951-9.

10. Kolotushkina EV, Moldavan MG, Voronin KY, Skibo GG. The influence of Hericium erinaceus extract on myelination process in vitro. Fiziol Zh. 2003:49(1):38-45.

11. Mori K, Obara Y, Hirota M, Azumi Y, Kinugasa S, Inatomi S, et al. Nerve growth factor-inducing activity of Hericium erinaceus in 1321N1 human astrocytoma cells. Biol Pharm Bull. 2008;31(9):1727-32.

12. Mori K, Obara Y, Moriya T, Inatomi S, Nakahata N. Effects of Hericium erinaceus on amyloid beta(25-35) peptide-induced learning and memory deficits in mice. Biomed Res. 2011;32(1):67-72.

13. Aruoma Ol, Kaur H, Halliwell B. Oxygen free radicals and human diseases. J R Soc Health. 1991;111(5):172-7.

14. Ames BN, Shigenaga MK, Hagen TM. Oxidants, antioxidants, and the degenerative diseases of aging. Proc Natl Acad Sci U S A. 1993;90(17):7915-22.

15. Abdullah N, Ismail SM, Aminudin N, Shuib AS, Lau BF. Evaluation of selected culinary-medicinal mushrooms for antioxidant and ACE inhibitory activities. Evid Based Complement Alternat Med. 2012;2012:464238.

16. Zhang Z, Lv G, Pan H, Pandey A, He W, Fan L. Antioxidant and hepatoprotective potential of endo-polysaccharides from Hericium erinaceus grown on tofu whey. Int J Biol Macromol. 2012;51(5):1140-6.

17. Han ZH, Ye JM, Wang GF. Evaluation of in vivo antioxidant activity of Hericium erinaceus polysaccharides. Int J Biol Macromol. 2013;52:66-71.

18. Zhishen J, Mengcheng T, Jianming W. The determination of flavonoid contents in mulberry and their scavenging effects on superoxide radicals. Food Chem. 1999;64(4):555-9.

19. Shimada K, Fujikawa K, Yahara K, Nakamura T. Antioxidative properties of xanthan on the autoxidation of soybean oil in cyclodextrin emulsion. J Agric Food Chem. 1992;40(6):945-8.

20. Reers M, Smiley ST, Mottola-Hartshorn C, Chen A, Lin M, Chen LB. Mitochondrial membrane potential monitored by JC-1 dye. Methods Enzymol. 1995;260:406-17.

21. Yao LH, Jiang YM, Shi J, Tomas-Barberan FA, Datta N, Singanusong R, et al. Flavonoids in food and their health benefits. Plant Foods Hum Nutr. 2004; 59(3):113-22.

22. Vauzour D, Vafeiadou K, Rodriguez-Mateos A, Rendeiro C, Spencer JP. The neuroprotective potential of flavonoids: a multiplicity of effects. Genes Nutr. 2008;3(3-4):115-26.

23. Vauzour D. Effect of flavonoids on learning, memory and neurocognitive performance: relevance and potential implications for Alzheimer's disease pathophysiology. J Sci Food Agric. 2014;94(6):1042-56. 
24. Giavasis I. Bioactive fungal polysaccharides as potential functional ingredients in food and nutraceuticals. Curr Opin Biotechnol. 2014;26:162-73.

25. Ho YS, Yu MS, Yang XF, So KF, Yuen WH, Chang RC. Neuroprotective effects of polysaccharides from wolfberry, the fruits of Lycium barbarum, against homocysteine-induced toxicity in rat cortical neurons. J Alzheimers Dis. 2010;19(3):813-27.

26. Chen G, Chen KS, Knox J, Inglis J, Bernard A, Martin SJ, et al. A learning deficit related to age and beta-amyloid plaques in a mouse model of Alzheimer's disease. Nature. 2000;408(6815):975-9.

27. Walsh DM, Klyubin I, Fadeeva JV, Cullen WK, Anwyl R, Wolfe MS, et al. Naturally secreted oligomers of amyloid beta protein potently inhibit hippocampal long-term potentiation in vivo. Nature. 2002;416(6880):535-9

28. Zhou ZY, Tang YP, Xiang J, Wua P, Jin HM, Wang Z, et al. Neuroprotective effects of water-soluble Ganoderma lucidum polysaccharides on cerebral ischemic injury in rats. J Ethnopharmacol. 2010:131(1):154-64.

29. Liu Y, Fukuwatari Y, Okumura K, Takeda K, Ishibashi K, Furukawa M, et al. Immunomodulating activity of Agaricus brasiliensis KA21 in mice and in human volunteers. Evid Based Complement Alternat Med. 2008;5(2):205-19.

30. Park SY. Potential therapeutic agents against Alzheimer's disease from natural sources. Arch Pharm Res. 2010;33(10):1589-609.

31. Yu MS, Leung SK, Lai SW, Che CM, Zee SY, So KF, et al. Neuroprotective effects of anti-aging oriental medicine Lycium barbarum against betaamyloid peptide neurotoxicity. Exp Gerontol. 2005;40(8-9):716-27.

32. Chen W, Cheng $X$, Chen J, Yi X, Nie D, Sun $X$, et al. Lycium barbarum polysaccharides prevent memory and neurogenesis impairments in scopolamine-treated rats. PLoS One. 2014:9(2):e88076.

33. Tsai M-C, Song T-Y, Shih P-H, Yen G-C. Antioxidant properties of watersoluble polysaccharides from Antrodia cinnamomea in submerged culture. Food Chem. 2007;104(3):1115-22

34. Malinowska E, Krzyczkowski W, Herold F, Łapienis G, Ślusarczyk J, Suchocki P, et al. Biosynthesis of selenium-containing polysaccharides with antioxidant activity in liquid culture of Hericium erinaceum. Enzyme Microb Technol. 2009;44(5):334-43.

35. Valko M, Leibfritz D, Moncol J, Cronin MT, Mazur M, Telser J. Free radicals and antioxidants in normal physiological functions and human disease. Int J Biochem Cell Biol. 2007;39(1):44-84.

36. Mohsenzadegan M, Mirshafiey A. The immunopathogenic role of reactive oxygen species in Alzheimer disease. Iran J Allergy Asthma Immunol. 2012:11(3):203-16.

37. Wang X, Su B, Siedlak SL, Moreira PI, Fujioka H, Wang Y, et al. Amyloid-beta overproduction causes abnormal mitochondrial dynamics via differential modulation of mitochondrial fission/fusion proteins. Proc Natl Acad Sci U S A. 2008;105(49):19318-23.

38. Abramov AY, Canevari L, Duchen MR. Beta-amyloid peptides induce mitochondrial dysfunction and oxidative stress in astrocytes and death of neurons through activation of NADPH oxidase. J Neurosci. 2004;24(2):565-75.

39. Reddy PH. Amyloid beta, mitochondrial structural and functional dynamics in Alzheimer's disease. Exp Neurol. 2009;218(2):286-92.

40. Eckert A, Keil U, Scherping I, Hauptmann S, Muller WE. Stabilization of mitochondrial membrane potential and improvement of neuronal energy metabolism by Ginkgo biloba extract EGb 761. Ann N Y Acad Sci. 2005; 1056:474-85.

41. Roth $A D$, Ramirez G, Alarcon R, Von Bernhardi R. Oligodendrocytes damage in Alzheimer's disease: beta amyloid toxicity and inflammation. Biol Res. 2005:38(4):381-7.

42. Kim HS, Lim JY, Sul D, Hwang BY, Won TJ, Hwang KW, et al. Neuroprotective effects of the new diterpene, CBNU06 against betaamyloid-induced toxicity through the inhibition of NF-kappaB signaling pathway in PC12 cells. Eur J Pharmacol. 2009;622(1-3):25-31.

43. Hu WX, Xiang Q, Wen Z, He D, Wu XM, Hu GZ. Neuroprotective effect of Atractylodes macrocephalaon polysaccharides in vitro on neuronal apoptosis induced by hypoxia. Mol Med Rep. 2014;9(6):2573-81.

\section{Submit your next manuscript to BioMed Central and we will help you at every step:}

- We accept pre-submission inquiries

- Our selector tool helps you to find the most relevant journal

- We provide round the clock customer support

- Convenient online submission

- Thorough peer review

- Inclusion in PubMed and all major indexing services

- Maximum visibility for your research

Submit your manuscript at www.biomedcentral.com/submit
Biomed Central 